\title{
lodine deficiency and brain development in the first half of pregnancy
}

\author{
Gabriella Morreale de Escobar* , María Jesús Obregón and Francisco Escobar del Rey \\ Instituto de Investigaciones Biomédicas Alberto Sols, CSIC \& UAM, Calle Arturo Duperier, 4, 28029 Madrid, Spain
}

\begin{abstract}
An inadequate supply of iodine during gestation results in damage to the foetal brain that is irreversible by mid-gestation unless timely interventions can correct the accompanying maternal hypothyroxinemia. Even mild to moderate maternal hypothyroxinemia may result in suboptimal neurodevelopment. This review mainly focuses on iodine and thyroid hormone economy up to mid-gestation, a period during which the mother is the only source for the developing brain of the foetus. The cerebral cortex of the foetus depends on maternal thyroxine $\left(\mathrm{T}_{4}\right)$ for the production of the 3',3,5-tri-iodothyronine $\left(\mathrm{T}_{3}\right)$ for nuclear receptor-binding and biological effectiveness.

Maternal hypothyroxinemia early in pregnancy is potentially damaging for foetal brain development. Direct evidence has been obtained from experiments on animals: even a relatively mild and transient hypothyroxinemia during corticogenesis, which takes place mostly before mid-gestation in humans, affects the migration of radial neurons, which settle permanently in heterotopic locations within the cortex and hippocampus. Behavioural defects have also been detected.

The conceptus imposes important early changes on maternal thyroid hormone economy that practically doubles the amount of $\mathrm{T}_{4}$ secreted something that requires a concordant increase in the availability of iodine, from 150 to $250-300 \mu \mathrm{g} \mathrm{I}_{\text {day }}{ }^{-1}$. Women who are unable to increase their production of $\mathrm{T}_{4}$ early in pregnancy constitute a population at risk for having children with neurological disabilities. As a mild to moderate iodine deficiency is still the most widespread cause of maternal hypothyroxinemia, the birth of many children with learning disabilities may be prevented by advising women to take iodine supplements as soon as pregnancy starts, or earlier if possible, in order to ensure that their requirements for iodine are met.
\end{abstract}

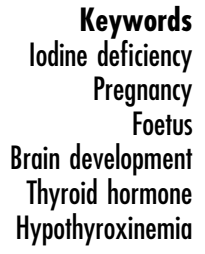

\section{Introduction}

The Declaration for the Survival, Protection and Development of Children made after the World Summit for Children convened by the United Nations in New York in 1989 stated that every mother has the right to an adequate iodine nutrition to ensure that her newborn child experiences normal brain development ${ }^{1}$. For this to occur, an adequate iodine intake has to be ensured very early in pregnancy and if all iodine deficiency disorders (IDD) are to be avoided, whatever their severity. This paper addresses the irreversible damage to the developing brain that can result from the deficiency of iodine if not corrected before mid-gestation, and when it is not accompanied by other environmental factors that interfere with the capacity of the thyroid gland to adapt through autoregulatory mechanisms. This paper will review three aspects of this process:

1. The changes in thyroid hormone metabolism that occur during the first half of pregnancy, both in the foetal brain and in the mother;
2. The increase in thyroid hormone synthesis during pregnancy, and the consequent increased requirement for iodine; and

3. The differences between the mother and foetus in the mechanisms by which they adapt to iodine deficiency (ID).

We will then review the information presently available on the morphological alterations detected in the brain of humans and other mammals, especially in the cortex, that occur before the onset of foetal thyroid hormone secretory activity, which are therefore related to the state of the maternal thyroid gland.

A causal relationship between inappropriate maternal thyroid function and damage to the developing brain has been suspected since the early 20th century, mostly on the basis of reports from localities in which ID occurs. It has only been during the last five decades, however, that this idea has received increasing, albeit indirect, support from epidemiological evidence (reviewed in references $2-10$ ). 
A series of studies in Papua New Guinea ${ }^{11,12}$ and in Andean regions where endemic goitre with cretinism occurs $^{13,14}$, showed that pregnant women in such places were unable to respond to the onset of pregnancy with an increase in circulating thyroxine (measured then by serum protein-bound iodine), which is the normal physiological response to the onset of pregnancy in women with an adequate iodine intake. It was also shown that to prevent the birth of cretins, interventions that corrected the ID (and the maternal hypothyroxinemia) were required very early in pregnancy and before mid-gestation at the latest $^{12,15,16}$. Since these studies, evidence has accumulated showing that treatment early in pregnancy is required not only to prevent cretinism, but also to avoid the lowered intelligence quotient suffered by the rest of the inhabitants of such areas ${ }^{17-21}$. ID was clearly recognised, after starvation, as the most frequent worldwide nutritional cause of mental retardation and cerebral palsy. The realisation of the scale of the problem has further increased over recent decades as evidence has accumulated showing that even mild and moderate degrees of ID are potentially damaging for neurodevelopment, and interventions are needed early in pregnancy to prevent them ${ }^{22,23}$.

\section{Changes in thyroid hormone metabolism that occur during the first half of pregnancy in the foetal brain}

As a result of the development of highly sensitive methods to estimate very low concentrations of iodothyronines in foetal fluids and tissues, and the development of transvaginal, ultrasound-guided puncture of the embryonic cavities to obtain samples from the foetal compartment without severing vascular connections with the mother, new and more reliable information has been obtained during the last two decades regarding maternal-foetal interrelationships during the first half of pregnancy. This information, as well as increasing the evidence that the thyroid hormone transferred from the mother to her foetus may trigger the biological events very early in pregnancy, has recently been reviewed extensively and in greater detail $^{8,10}$, and so it is briefly summarised here.

\section{Thyroxine $\left(T_{4}\right)$, tri-iodiotbyronine $\left(T_{3}\right)$, reverse tri-iodiotbyronine $\left(r \mathrm{~T}_{3}\right)$ and TSH in fluids of the foetal compartment}

The hormones $\mathrm{T}_{4}, \mathrm{~T}_{3}$ and $\mathrm{r}_{3}$ have been found in coelomic and amniotic fluids from 5.8 to 11 weeks post-menstrual age (PMA), which is 3.8-9 weeks postconceptional age ${ }^{24}$. The concentration of $\mathrm{T}_{4}$ in the coelomic fluid was positively correlated with the concentration in the mother's circulation, but values were extremely low compared with values recorded for the mother ${ }^{24}$. The concentration of $\mathrm{T}_{3}$ was at least ten-fold lower than $\mathrm{T}_{4}$, but the concentration of $\mathrm{rT}_{3}$ was clearly higher than $\mathrm{T}_{4}{ }^{24}$; these findings confirmed the efficiency of the placental barrier.
Concentrations of these hormones in the coelomic fluid were higher than in the amniotic compartment. Because of the minute amounts of the iodothyronines found in these fluids, their possible biological significance has been questioned.

A second study was performed on serum samples and up to 17 weeks PMA $^{24}$. A method was developed to estimate the concentration of free $\mathrm{T}_{4}$ ( $\mathrm{fT}_{4}$ ), which confirmed that the concentration of $\mathrm{T}_{4}$ in foetal fluids, including serum, is more than 100-fold lower than in maternal serum and the concentration of $\mathrm{T}_{3}$ is even lower ${ }^{25}$. However, the proportion of $\mathrm{T}_{4}$ that is not bound to proteins is much higher, as a result of which the concentrations of $\mathrm{T}_{4}$ that is available to developing tissues, namely the free $\mathrm{T}_{4}$, reaches concentrations that are similar to those that are biologically active in the mothers ${ }^{25}$.

The $\mathrm{fT}_{4}$ concentration in the foetal fluids is the result of the interaction between the concentrations of the $\mathrm{T}_{4}$-binding proteins and the maternal $\mathrm{T}_{4}$, or fT 4 that has passed through the placental barrier. The $\mathrm{T}_{4}$ binding capacity of the proteins in foetal fluids is determined ontogenically, it is independent of the maternal thyroid status, and is far in excess of the amounts of total $\mathrm{T}_{4}$ that reach the foetal fluids. Thus, the availability of $\mathrm{fT}_{4}$ to embryonic and foetal tissues is ultimately determined by the maternal circulating $\mathrm{T}_{4}$ or $\mathrm{fT} 4$ and would decrease in hypothyroxinemic women, even if they are clinically euthyroid. The results also explain why an efficient barrier to maternal thyroid hormone transfer is actually necessary: if $\mathrm{T}_{4}$ and $\mathrm{T}_{3}$ reached the same concentrations in maternal serum and foetal fluids, the developing tissues would be exposed to inappropriately high, and possibly toxic, concentrations of free iodothyronines. Both a decrease $^{8}$ and an inordinately high increase $\mathrm{in}^{26}$ in the availability of $\mathrm{fT}_{4}$ and/or $\mathrm{fT}_{3}$ could result in adverse effects on the timely sequence of thyroid hormone-sensitive developmental events in the foetal human brain.

It was also observed that the concentration of TSH circulating in the foetal serum was much higher than in the mother's circulation, ranging from 2.9 to $7.2 \mathrm{mIUl}^{-1}$, with a mean value of 4.31 (SD 0.36) mUI per $1^{25}$. The samples analysed in this study had been obtained before severing the maternal-foetal vascular connections. Although such values were not anticipated, they actually corroborated those reported by Thorpe-Beeston et al. throughout foetal life using samples collected by cordocentesis ${ }^{27}$, again without disturbing maternal-foetal connections. ThorpeBeeston et al. showed that the foetal serum TSH concentration throughout pregnancy was well above the maternal TSH concentration, with foetal concentrations up to $12 \mathrm{mIUl}^{-1}$ near full term ${ }^{27}$. Foetal TSH was positively correlated with foetal $\mathrm{fT}_{4}(r=0.896, P<0.001)^{27}$. Foetal TSH has a higher bioactivity than maternal TSH, and its synthesis is not under hypothalamic control, as shown by the high cord serum TSH concentration found in anencephalic foetuses ${ }^{28,29}$. A concentration of foetal TSH 
up to about $12 \mathrm{mIUl}^{-1}$ should not be interpreted as evidence per se of a hypothalamic-pituitary feedback response to hypothyroidism, because the reference range that is used for normal foetuses is $3-14 \mathrm{mIU}$ per $1^{30}$. Receptors for TSH have been found throughout the human foetal brain ${ }^{31}$ and are believed to mediate cyclic AMP-independent biological effects of TSH that might be acting as a growth factor for brain development ${ }^{32}$. This possibility is supported by the inclusion of TSH among the glycoprotein hormone family constituting a subset of the cystine-knot growth factor superfamily ${ }^{33}$ and is discussed further below.

\section{Nuclear thyroid hormone receptors in the foetal brain}

The presence of thyroid hormone receptors (TRs) early in the development of the human foetal brain supports the hypothesis that developmental events sensitive to thyroid hormones might already occur before mid-gestation. These were detected in the earliest samples of the cerebral cortex studied 9 weeks PMA by Bernal and Pekonen ${ }^{34}$, with the concentration increasing at least ten-fold by 18 weeks ${ }^{35}$. The occupation of the TRs by $\mathrm{T}_{3}$ was $25-30 \%$ throughout the study period, despite the very low serum concentration of this iodothyronine. This very important finding supports the hypothesis that the biological effects of the hormone might already be occurring in the cerebral cortex during the first trimester of human pregnancy. A recent study by Iskaros et al. ${ }^{36}$ has confirmed the early expression of THRA and THRB genes in the whole foetal brain studied between 8.1 and 13.9 weeks PMA. Expression of the TR-beta1, TR-alpha1 and c-erbAalpha2 mRNAs was detected in the 8.1 weeks brain sample, with TR-alpha1 being the predominant form in early development, increasing steadily up to 13.9 weeks. The same happened to the c-erbA-alpha2 mRNA variant. The expression of TR-beta1 appeared to present a more complex ontogenic pattern. The results of this study are indicative of the important role of TRs in mediating the developmental effects of maternal thyroid hormones early in pregnancy. The authors moreover suggest that the repressor activity of unliganded TR-alpha1 on basal gene transcription $^{37}$ may also become relevant when the maternal supply of hormone decreases, and the proportion of the unliganded isoform increases.

\section{Iodothyronines and deiodinase activities in the foetal brain}

The ontogenic patterns of the concentrations of $\mathrm{T}_{4}, \mathrm{~T}_{3}$ and $\mathrm{rT}_{3}$, and the activity of deiodinases 1,2 and 3 (D1, $\mathrm{D} 2$ and D3) has now been studied in nine different areas of the brain of foetuses 13-20weeks PMA and in premature infants who died at 24-42 weeks PMA ${ }^{38}$. The developmental patterns of the iodothyronines, and the activity of D2 and D3, showed both spatial and temporal specificity, but with divergence in the cerebral cortex and other brain areas, especially the cerebellum (Fig. 1). The concentration of $\mathrm{T}_{3}$ increased in the cerebral cortex between 13 and 20 weeks PMA to reach a concentration similar to those reported in adults, despite the very low circulating $\mathrm{T}_{3}$ concentration. The data support the idea that $\mathrm{T}_{3}$ in the human cerebral cortex is also locally generated from $\mathrm{T}_{4}$, as shown for the foetal rat brain ${ }^{39}$. Considerable D2 activity has indeed been found in the human cerebral cortex where the activity of D3 was very low. In contrast, the cerebellar $\mathrm{T}_{3}$ concentration was much lower than in age-paired cortices and increased only after mid-gestation, probably because cerebellar D3 activity reached the highest of the values found in the brain areas that were studied and decreased only after mid-gestation. Other regions with a high D3 activity such as the midbrain, basal ganglia, brain stem, spinal cord and hippocampus, also had a low $\mathrm{T}_{3}$ concentration until D3 activity started decreasing after mid-gestation. These findings support the hypothesis that $\mathrm{T}_{3}$ is indeed required by the human cerebral cortex before midgestation, when the mother is the only source of $\mathrm{fT}_{4}$ in foetal fluids that is available to tissues. These results appear to confirm the important roles of D2 and D3 in the local bioavailability of cerebral $\mathrm{T}_{3}$ during foetal life: D2 generates $\mathrm{T}_{3}$ from $\mathrm{T}_{4}$, and $\mathrm{D} 3$ protects brain regions from excessive $T_{3}$ until the hormone is required for their differentiation.

\section{Changes in thyroid hormone metabolism that occur during the first half of pregnancy in the mother}

\section{The initial transient surge of maternal circulating $\boldsymbol{F T}_{4}$}

It is obviously of great importance to define the changes in thyroid hormone synthesis, secretion and metabolism that occur during normal pregnancy to ensure that the developing foetal cerebral cortex is supplied with sufficient $\mathrm{T}_{4}$; this supply is entirely of maternal origin during the first half of gestation. When it was observed that the concentration of circulating $\mathrm{T}_{4}$ was higher in pregnant than in non-pregnant women initially, it was believed that this was a direct consequence of the oestrogen-stimulated increase of circulating thyroxine binding globulin (TBG) and of TBG-moieties that are more highly sialylated and have a longer biological half-life. The increased concentration of circulating $\mathrm{T}_{4}$ was deemed necessary in order to keep the concentration of circulating $\mathrm{fT}_{4}$ within the normal range. However, the expected transient decrease in $\mathrm{fT}_{4}$ followed by a rise in TSH, necessary to attain the new equilibrium, was not detected.

We now know that the increases in $\mathrm{T}_{4}$ and TBG do not occur simultaneously, and the $\mathrm{fT}_{4}$ concentration is actually significantly increased for several weeks before the concentration of TBG reaches a plateau at midgestation $^{40}$. The increase in concentration of human chorionic gonadotropin (hCG) in the maternal and foetal 



Fig. 1 Ontogenic changes in the concentrations of $\mathrm{T}_{4}, \mathrm{~T}_{3}$ and $\mathrm{rT}_{3}$ in the human cerebral cortex ( 3 upper panels) and cerebellum (3 lower panels) up to mid-gestation, a developmental period when the mother is the only source of thyroid hormone for the developing foetus (data from reference 38). In the cerebral cortex D2 activity is high, and D3 is very low; in the cerebellum D2 is lower than in the cerebral cortex, but D3 activity is very high and inactivates both $\mathrm{T}_{4}$ and $\mathrm{T}_{3}$, preventing their increase in this cerebral area. During this period $\mathrm{T}_{4}$ in the foetal serum increases about five-fold, from 3 to $15 \mathrm{pmol} \mathrm{ml}^{-1}$, whereas circulating $T_{3}$ remains very low, about $0.5 \mathrm{pmol} \mathrm{ml} \mathrm{m}^{-1}$ and does not increase with $\mathrm{PMA}^{25}$. The curves appearing in the different panels were those obtained by curve estimation regression analysis ${ }^{38}$. Both cerebral cortex $T_{4}$ and $T_{3}$ were fitted to gestational age using a quadratic function with positive regression coefficients, with $P=0.003$ and $P=0.001$ respectively. In the cerebellum $\mathrm{T}_{4}$ was fitted to gestational age by a quadratic function with a negative regression coefficient, $P=0.006$.

compartments is essential to maintain the pregnancy and is imposed by the presence of the conceptus. During this period a woman's thyroid is under the control of the high concentration of hCG and hCG-related molecules that have TSH-like activity. During early pregnancy, when these are at their highest concentration, secretion of both $\mathrm{T}_{4}$ and $\mathrm{T}_{3}$ is stimulated to the point that maternal circulating TSH concentration is suppressed. A plot of the mean maternal serum hCG concentration as a function of gestational age shows a peak concentration at the end of the first trimester, with a reciprocal fall in the TSH concentration (Fig. 2). This phenomenon has even been observed in a case of thyroid hormone resistance ${ }^{41}$ : the already very high serum $\mathrm{T}_{4}$ and $\mathrm{T}_{3}$ concentration increased further at the onset of pregnancy and reached a peak value when circulating hCG was at its highest at 10-12 weeks gestation. These changes were accompanied by a reciprocal fall in serum TSH concentration that was temporarily suppressed, as already shown in Fig. 2 for normal women.

This initial adaptation of maternal thyroid physiology to the presence of the foetus may well be one more example of the control exerted by the conceptus on the maternal endocrine system. One possible interpretation is that it is essential for the conceptus to ensure, for its own benefit, the high maternal $\mathrm{fT}_{4}$ concentration that is needed for early neural development. To achieve this, it would be necessary to override transiently the control of the maternal thyroid function that is usually exerted through the negative hypothalamic-pituitary-thyroid feedback mechanism.

\section{The increased production of $T_{4}$ by the maternal thyroid requires an increased supply of iodine}

Maternal thyroid hormone production during the first half of pregnancy obviously has to increase very soon after its onset in order to ensure the early surge in circulating $\mathrm{fT}_{4}$, and taking into account the increase in plasma volume that occurs. There is also an increased degradation of the iodothyronines by the very high activity of D3 in the uterine-placental unit, possibly a consequence of the increased oestrogen concentration ${ }^{42}$. The increase in size of the maternal $\mathrm{T}_{4}$ pool early in pregnancy has not yet been defined precisely, and may differ in the same woman between pregnancies. The information available suggests that it imposes a considerable burden on the maternal thyroid gland ${ }^{43}$. It has been known for years that hypothyroid women very often have to increase their dose of $\mathrm{T}_{4}$ during pregnancy ${ }^{44,45}$ in order to normalise their TSH concentration, namely to decrease it below the upper limits of the normal reference range. A very recent study has not only confirmed this practice, but has moreover shown that the levothyroxine dose has already to be increased by the fifth week of gestation and by approximately $50 \%$ in order to keep the TSH 
1558
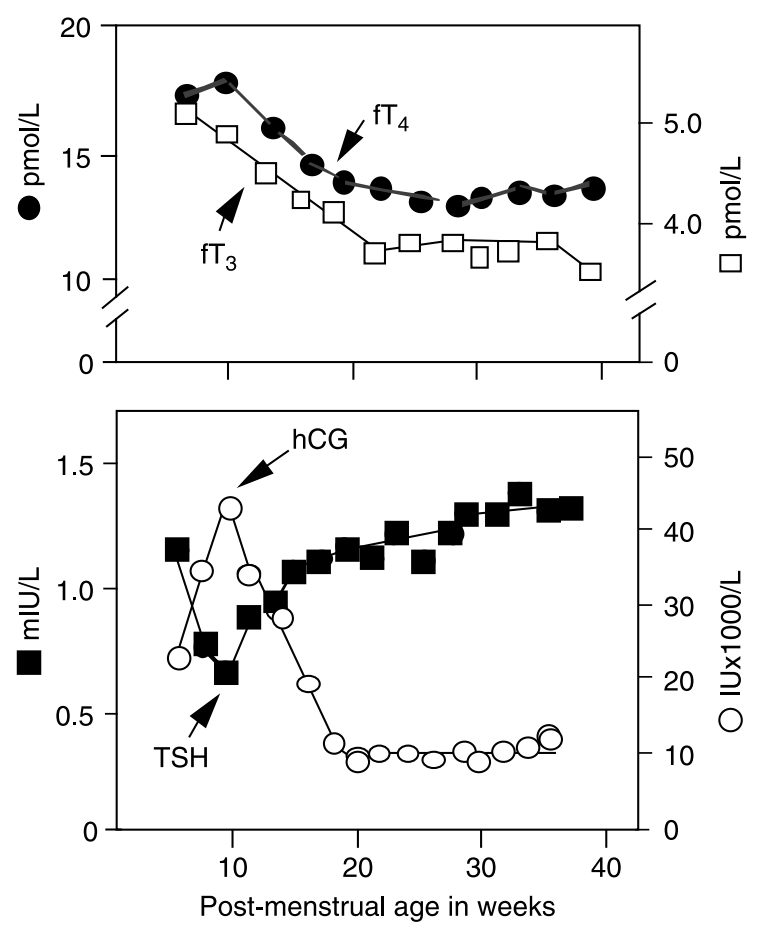

Fig. 2 The upper panel shows the increased maternal serum $\mathrm{fT}_{4}$ and $\mathrm{fT}_{3}$ concentrations that are observed during early phases of normal pregnancy, and their decrease during the second and third trimester. The lower panel shows the concomitant changes in maternal circulating human chorionic gonadotrophin (hCG) imposed by the foetus, responsible for the secretion of $T_{4}$ and $T_{3}$ by the mother's thyroid, and the mirror image in circulating TSH, maximally suppressed when the hCG concentration (and $\mathrm{fT}_{4}$ and $\mathrm{fT}_{3}$ concentrations) are highest. Drawn using mean values reported by Glinoer ${ }^{40}$. The numbers appearing in the $y$-axis of the lower panel should be multiplied by 1000 to calculate the concentrations of hCG in IU.

concentration within the normal range ${ }^{46}$. Even this early and significant increase of the $\mathrm{T}_{4}$ dose, however, failed to reproduce the first trimester $\mathrm{fT}_{4}$ peak and $\mathrm{TSH}$ nadir found in normal pregnant women. We have proposed that an even greater increase in the levothyroxine dose might have been needed if the goal of treatment had been to reach the physiological trimester-specific $\mathrm{fT}_{4}$ concentration, including the suppressed TSH concentration characteristic of pregnant women with normal thyroid status $^{10}$. This is illustrated in Fig. 2. From such information, we may conclude that a $50 \%$ increase in the daily $\mathrm{T}_{4}$ requirement already imposes a concordant increase in the iodine intake as soon as pregnancy starts. This possibility is in conceptual agreement with the marked increase in iodine requirements during pregnancy and lactation ${ }^{5,43,47}$, that is, independent of other possible pregnancy-related changes that may occur in iodine metabolism.

If we accept the importance of the early maternal $\mathrm{fT}_{4}$ surge imposed by the conceptus, we might be able to derive the increase in iodine intake-indirectly estimated from the urinary I excretion (UI) — that would be necessary to ensure it. An example of this is shown in Fig. 3a, based on a study performed in pregnant women in Madrid ${ }^{48}$



GM de Escobar et al.

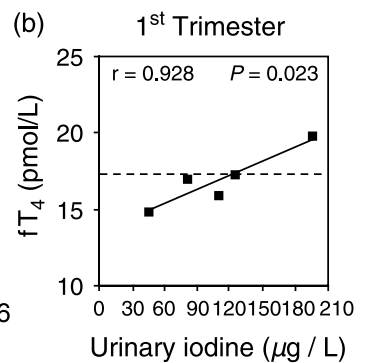

KI supplement:

- No

Fig. 3 Panel a shows an example of the effects of the iodine intake on the first trimester $\mathrm{fT}_{4}$ surge and on $\mathrm{fT}_{4}$ values throughout pregnancy, based on data from a study of pregnant women with a median urinary iodine of $90-95 \mu \mathrm{g} \mathrm{II}^{-1}$ throughout gestation, and of those from the same area advised to take $\mathrm{KI}$ supplements (approximately $250 \mu \mathrm{glday}^{-1}$ ) from early pregnancy, and a mean urinary iodine excretion double that of the non-supplemented women ${ }^{9,48}$. First, trimester median $\mathrm{fT}_{4}$ values were 16.9 and $19.9 \mathrm{pmoll}^{-1}$, respectively, for the non-supplemented and KI-supplemented women. The shaded area corresponds to the $\mathrm{fT}_{4}$ reference range for the general population. Panel b shows the effect of an iodine intake that is inadequate for pregnancy on the first trimester $\mathrm{fT}_{4}$ surge. The latter is blunted when the intake results in an iodine excretion below $180-200 \mu \mathrm{gII}^{-1}$, corresponding approximately to an intake of $250-300 \mu \mathrm{g} \mathrm{day}^{-1}$. Median first trimester $\mathrm{fT}_{4}$ and urinary iodine values are from different studies using the same protocols and comparable methodology for the determination of $\mathrm{fT}_{4}{ }^{47-51}$.

where a survey of 2150 schoolchildren using thyroid palpation and UI concentration disclosed a situation of very mild ID. The proportion of pubertal girls with goitre, however, reached $18 \%$. This raised the question of whether or not their iodine intake would later be sufficient to meet the increased requirements of pregnancy and lactation. Indeed, pregnant women from this area were found to have a median UI concentration of $90-95 \mu \mathrm{gl}^{-1}$ throughout gestation; none of them were either clinically or subclinically hypothyroid, as none had an increased serum TSH concentration. The women from the same area were advised to take supplements of potassium iodide (KI) of about $250-300 \mu \mathrm{gIday}^{-1}$ from early in their pregnancy, their UI excretion increased to approximately $180-200 \mu \mathrm{gl}^{-1}$ by the 2 nd and 3rd trimesters. During the 1st trimester, a commensurate increase in UI was not observed in the KI-supplemented women, possibly because thyroid iodine stores were being replenished. Despite this, the mothers' circulating $\mathrm{fT}_{4}$ concentration increased significantly during the 1st trimester: the median $\mathrm{fT}_{4}$ values were 16.9 and $19.9 \mathrm{pmoll}^{-1}$, respectively, for the non-supplemented and KI-supplemented women. Moreover, an early peak in $\mathrm{fT}_{4}$ concentration was observed in the KI-supplemented women, but was absent in the non-supplemented group. Figure $3 \mathrm{~b}$ shows the dependence of the 1 st trimester peak of $\mathrm{fT}_{4}$ on the iodine intake: a correlation was found between the 1st trimester median $\mathrm{fT}_{4}$ concentration and the median UI concentration corresponding to different studies ${ }^{48-52}$ that have used the same protocols and similar methods to determine 
the concentration of $\mathrm{fT}_{4}$. Such results, which are similar to those obtained by others (i.e. reference 43), emphasise that a relative maternal ID impairs the capacity of the maternal thyroid to secrete appropriate amounts of $\mathrm{T}_{4}$, and the initial $\mathrm{fT}_{4}$ surge is blunted, the more so the greater the $\mathrm{ID}^{43}$. This impairment is not necessarily detected if the mother's serum TSH concentration is being measured because the concentration usually remains within the normal range in iodine deficient women who are otherwise healthy. On the contrary, both an increase in the serum $\mathrm{T}_{3} / \mathrm{T}_{4}$ ratio and the thyroglobulin ( $\mathrm{Tg}$ ) concentration above the normal range for pregnant women reflect an increasing degree of maternal ID $^{40,42}$. This is discussed further below.

\section{Mechanisms of adaptation of the mother and the foetus to ID}

As summarised in the previous section, the iodine intake of a pregnant women has to increase by about 100\% to allow her thyroid to produce enough $\mathrm{T}_{4}$ to meet foetal requirements early in pregnancy. This is often not ensured, and she faces a relative ID. If this continues during the second half of pregnancy, the foetal thyroid will also be iodine deficient. The mother and the foetus, however, respond differently to this condition; the mother maintains euthyroidism, whereas the foetus is hypothyroid.

\section{Maintenance of euthyroidism in iodine deficient women}

The very low concentration of circulating TSH characteristic of early pregnancy, which results from an increase in $\mathrm{fT}_{4}$ and $\mathrm{fT}_{3}$ secreted by the thyroid gland under the influence of hCG, is not the only reason why a relative maternal hypothyroxinemia may be missed when relying on an increased TSH concentration for its detection. A relative ID in the mother rapidly triggers the autoregulatory mechanisms by which the thyroid adapts to changes in the availability of iodine. It is important to realise that these mechanisms occur before changes in the concentration of circulating TSH, and operate independently of thyroid stimulation by TSH, not only in experimental animals ${ }^{53,54}$ but also in human beings ${ }^{55}$. The immediate and rapid response of a normal thyroid gland to a low concentration of circulating iodide is an increase in vascularity, blood flow, iodide trapping, acinar cell height and hyperplasia. All these changes have been described without, or before, any significant increase in circulating TSH concentration or a decrease in $\mathrm{T}_{4}$, and are correlated with the degree of depletion of iodine in the gland. Among the many autoregulatory responses that occur $^{56}$, the synthesis and secretion of thyroid hormones is altered and switched towards a preferential use of the decreasing iodine supply to favour the secretion of $\mathrm{T}_{3}$ over $\mathrm{T}_{4}$. As a consequence, the concentration of circulating $\mathrm{T}_{4}$ decreases, but the concentration of $\mathrm{T}_{3}$ does not, and may actually be higher, thus preventing both the appearance of clinical hypothyroidism ${ }^{57}$ and an increase in the serum TSH concentration above the normal reference range ${ }^{58}$. Indeed, an increased serum TSH concentration is rarely found in populations which have ID alone ${ }^{59}$. Even when ID is very severe, the increase in circulating TSH is not commensurate with the very high values observed in hypothyroid patients with similarly decreased $\mathrm{T}_{4}$ and $\mathrm{fT}_{4}$ concentrations who also have a decreased circulating $\mathrm{T}_{3}$ concentration. An increased concentration of $\mathrm{Tg}$ and a higher $\mathrm{T}_{3} / \mathrm{T}_{4}$ ratio are much more frequent finding, even in mild to moderate ID. In the seminal studies of Glinoer et al. of the thyroid function of pregnant women from a population with a moderate ID, TSH concentrations above the normal range were not found, even among women with the lowest first trimester $\mathrm{fT}_{4}$ concentration, whereas an increased $\mathrm{T}_{3} / \mathrm{T}_{4}$ molar ratio and serum $\mathrm{Tg}$ concentration were observed from the onset ${ }^{40}$. Thus, the iodine deficient pregnant women were hypothyroxinemic, in as much as they could not maintain the trimester-specific $\mathrm{fT}_{4}$ concentration, but were clinically and biochemically euthyroid as long as their circulating $\mathrm{T}_{3}$ concentration was not decreased.

Inhabitants of iodine deficient areas including pregnant women are, however, frequently incorrectly referred to as being hypothyroid. This misconception is likely to have been compounded by the indiscriminate inclusion in the well known tables enumerating all IDDs ${ }^{3}$ of findings from areas with ID (where neurological cretins are born) together with those from areas where factors other than ID are impairing thyroid function (where myxoedematous cretinism prevails) ${ }^{60}$. To further complicate the issue, although the maintenance of a normal $\mathrm{T}_{3}$ concentration by inhabitants of areas with ID alone results in their overall euthyroidism, they may suffer from selective hypothyroidism of tissues, such as the brain, that depend mostly on $\mathrm{T}_{4}$ for the local availability of $\mathrm{T}_{3}{ }^{3}$. This continued selective cerebral hypothyroidism appears to impair cerebral functions at all ages, until the correction of the ID results in the normalisation of circulating $\mathrm{T}_{4}$. When ID is present during early foetal development, however, most of the damage to the central nervous system (CNS) is no longer reversed by the later correction of the micronutrient deficiency.

\section{Hypothyroidism of the iodine deficient foetus and newborn}

It is important to realise that the above comments relate to an iodine-deficient pregnant woman, but not to her foetus or newborn infant, as they have not yet developed the autoregulatory mechanisms for rapid adaptation to changes in the amounts of circulating iodine ${ }^{61}$; these mechanisms only become fully operative after birth. As a consequence, the shift towards the preferential secretion of $\mathrm{T}_{3}$, which constitutes the successful adaptive response 
to insufficient iodine of the mother in order to maintain euthyroidism, does not occur in the foetus. The scarcity of iodine is accompanied by a decreased synthesis and secretion of both $\mathrm{T}_{4}$ and $\mathrm{T}_{3}$. The concentration of the latter is no longer maintained within normal ranges and this results in hypothyroidism, both clinical and biochemical, with an above normal concentration of circulating TSH. The latter change is in conceptual agreement with the observation that the proportion of newborns with a concentration in whole blood of TSH $>5 \mathrm{mIUl}^{-1}$ is greater than $3 \%$ in populations with ID. This proportion is used to classify the degree of ID in a population ${ }^{62}$. Statements pertaining to the thyroid status of the iodine deficient mother should not be applied to the foetus, as they are not necessarily the same. Up to mid-gestation, the possible damage to the CNS suffered by the foetus would be a consequence of the hypothyroxinemia of an otherwise euthyroid mother; after mid-gestation it would be caused by persisting maternal hypothyroxinemia, aggravated by hypothyroidism in the foetus.

\section{Morphological alterations in the brain caused by ID before the onset of foetal thyroid hormone secretion}

As will be seen, the information available regarding the irreversible damage caused by ID solely through early hypothyroxinemia of the mother is scarce when compared with the abundant literature on the damaging effects of combined maternal hypothyroxinemia and foetal hypothyroidism.

\section{Effects of ID on buman brain development}

The neuropathology caused by ID is poorly described and is restricted to few observations, mostly performed in adult cretins ${ }^{63}$. These observations have been made on people from areas where the mixed type of cretinism occurs, and it is therefore difficult to characterise alterations that might have been due merely to early maternal hypothyroxinemia, as opposed to life-long exposure to cerebral and/or clinical hypothyroidism. Information is now being obtained on adult cretins by non-invasive techniques, such as computerised tomography $^{64}$ or magnetic resonance imaging (MRI) ${ }^{65,66}$. The studies of Andean cretins show widespread atrophy of the cerebral cortex and subcortical structures of the pons and mesencephalon, with corresponding enlargement of the basal cisterns, the lateral ventricles and the sulci over the surfaces of the cerebral cortex ${ }^{64}$. The MRI images of three cretins from China showed a remarkably normal overall appearance, except for hyperintensities on T1 weighted images in the region of the globus pallidus and substantia nigra ${ }^{65,66}$.

More informative with respect to possible neuropathological findings related to early maternal hypothyroxinemia caused by ID are the studies summarised by
Jia-Liu et al. ${ }^{67}$ that had previously documented in greater detail the results obtained from aborted foetuses in an area of China where severe ID and cretinism occur ${ }^{68,69}$. These foetuses were compared with foetuses from mothers living in an area where iodine supplements had been given for five years and foetuses from mothers living in an area without ID. The results are not easy to interpret as data on the UI concentration of the inhabitants and their $24 \mathrm{~h}{ }^{131} \mathrm{I}$ uptake indicated that even the supposedly non-deficient subjects were moderately iodine deficient before iodine supplementation. The foetuses were obtained at the 4 th, 5th, 6th, 7th and 8th months of gestation. No morphometric or cytoarchitectural findings were reported from foetuses obtained at 4 th and 5 th month. In the foetuses obtained at the 6th and 8th month of gestation, some that came from the iodine deficient population had a lower brain weight. At 6 months of gestation, the cerebral cortices of various areas were not well differentiated, only 3 layers were distinguishable, and the cortex nerve cells consisted mostly of undifferentiated neuroblasts. No mitoses were observed and apical dendrite budding was seen, but no basal dendrites were apparent. No myelination was detected. Two of six foetuses with a low brain weight had an increased cell density. At 8 months of gestation the cerebral cortices of all areas examined were clearly differentiated into 6 layers and cells were recognisable as neuroblasts, pyramidal cells, granular cells, astrocytes, etc. The dendrites of the pyramidal cells were developed, yet no myelination was detected. Heterotopic nerve cells were observed in the cortical layers and in the underlying white matter in greater numbers in the foetuses from the iodine deficient population, indicating that more than the normal number of neurons were not in their 'assigned' layer. Again two out of five foetuses had a low brain weight and cell density was increased. The authors concluded that 'Although the material studied in the present paper and the above mentioned differences were relatively small,... results suggest that prenatal ID exhibits certainly a depressive effect on the brain in some of the foetuses in the endemic goitre and cretinism areas retarding its development ${ }^{67}$.

\section{Effects of ID in animal experiments}

\section{Experimental studies in sheep}

In the 1980s, pioneering and thorough studies of the effects of ID on brain development in sheep were initiated in Australia by Hetzel and colleagues. In sheep, a greater part of brain development occurs in utero as compared with the human newborn, and newborn lambs are more mature than babies. Moreover, placentation is quite different from that in humans, being epitheliochorial in sheep and haemochorial in humans. Most existing information indicates that the sheep placenta is also more impermeable to thyroid hormones than the human placenta. 
The experimental sheep were fed on a low iodine diet developed specifically for the studies ${ }^{70}$, which were fully reviewed in $1994^{71}$. After being fed on the diet for five months the ewes were mated and foetuses were obtained 56, 70, 98 and 140 days later or nearing full term, and compared with age-matched controls from ewes given the same diet but supplemented either with KI or iodised oil injections ${ }^{72}$. The iodine deficient ewes had a markedly lower concentration of serum $\mathrm{T}_{4}$ and a higher TSH concentration. In contrast to the findings in women with ID, the sheep did not maintain a normal $\mathrm{T}_{3}$ concentration, and were clinically hypothyroid, as shown by their frequent foetal loss. Hyperplasia of the foetal thyroid was evident at day 56 , and thyroid hypertrophy by day 70 . The foetal plasma $\mathrm{T}_{4}$ concentration was very low in all iodine deficient foetuses and did not increase during development, whereas an increase was observed in the foetuses from the iodine-supplemented ewes. At day 140 the iodine deficient foetuses were goitrous and grossly hypothyroid, had no wool coat, subluxation of the leg joints, and a dome-like appearance of the head due to poor skeletal maturation. Their brains weighed significantly less than the brains of the controls and their total DNA content was lower. There were morphological changes in the cerebellum and cerebral hemispheres clearly indicating poor maturation. Interestingly, these changes were more severe than observed in foetuses, which had been thyroidectomised between day 50 and 60 after conception $^{73}$. In the cerebellum of iodine deficient lambs studied 140 days after conception a reduced migration of cells from the external to the internal granular layer was observed, and there was an increased density of the Purkinje cells with reduced arborisation within the molecular layer. In the visual and motor cortices, as well as in the CA1 and CA4 regions of the hippocampus, cells were more densely packed. There was also evidence of retarded myelination and higher water content. A lower brain weight and brain DNA content were also seen at day 70, and were interpreted as evidence that neuroblast multiplication had been impaired. The major phases of neuroblast multiplication take place in sheep between days 40 and 80 after conception, which corresponds to 11-18 weeks gestation in humans, that is, before midgestation. This is the period of major interest for the present review, as it might disclose the possible effects of maternal hypothyroxinemia alone on brain development, which occur before foetal hypothyroidism could also play a role. In this respect it is interesting that the alterations in brain development observed in the iodine deficient foetuses at day 140 were more severe than those resulting from foetal thyroidectomy at days 50 to $60^{73}$. This observation suggests an influence of maternal hypothyroxinemia on the development of the brain of iodine deficient lambs, because the maternal thyroid status of the thyroidectomised foetuses was normal. Another important finding was that injection of iodised oil into iodine deficient ewes 100 days after conception ${ }^{74}$ decreased most of the differences between the foetuses of iodine deficient dams examined at 140 days and their controls, but brain weight, cell numbers and counts (density) of synapses in the cortex were not fully restored. These findings support the conclusion that an early lack of maternal thyroid hormones in iodine deficient ewes had irreversibly affected the brain development of the foetus, despite the evidence that there is less maternal-foetal transfer of thyroid hormones in sheep than in humans $s^{2,71,75}$.

\section{Experimental studies in marmosets (Callithix jacchus jacchus), a primate}

The same group of investigators also studied the effects of a low iodine diet, developed especially for marmosets, on the brain development of their progeny ${ }^{76}$. These animals are also much more mature at birth than human babies. The brain of iodine deficient marmosets and controls born to marmosets on the same diet but supplemented with KI, was only studied at birth, which was 150 days after conception. The progeny from both 1 st and 2 nd pregnancies were studied ${ }^{77}$. The marmoset mothers and newborns were more severely iodine deficient and hypothyroxinemic and had larger goitres during their 2nd pregnancy, probably because they had been fed on the diet for a longer period than the six months preceding the 1st pregnancy. The reproductive performance of the iodine deficient marmosets in both pregnancies was similar to that of the controls when assessed in terms of the number of twins and triplets born. The newborn iodine deficient marmosets at birth appeared normal in terms of body weight, but showed some sparsity of hair growth; there was no evidence of significant skeletal retardation i.e. normal epiphyseal development. The iodine deficient marmosets were, however, lacking in strength, and were unable to cling to their parents, who rapidly abandoned them. The newborns died within a few days from malnutrition and hypothermia, thus forfeiting the initial aim of performing behavioural studies. All the changes observed in these newborns were more clearly seen in the 2nd litters. There was a greater reduction in brain weight, especially in the cerebellum, brain cell numbers were reduced in the cerebellum and brainstem, and cell size was reduced in the cerebral hemispheres. Histological examination revealed morphological changes in the cerebellum and cerebral hemispheres. In the cerebellum there was an increase in the thickness of the external germinal layer indicative of impaired cell acquisition. There was a decrease in total area and molecular layer area, and an increase in Purkinje cell linear density, and other changes that implied diminished ascending and lateral extensions of their dendrites. In the cerebral hemispheres an increase was observed in the density of neuronal cell bodies in the granular band and a decrease in synaptic counts in the layer between the pia mater and 
the supraglandular band of the visual cortex. The greater severity of the changes in the offspring of the 2nd pregnancy when compared with the 1st was interpreted as confirmation of the importance of maternal and foetal thyroid function in relation to brain development in a primate, but unfortunately the design of the study did not permit conclusions regarding the importance of maternal hypothyroxinemia alone during early foetal brain development.

\section{Experimental studies in rats}

Much experimental work on the effects of ID on the brain has been done in rats (reviewed in references $2,3,7,8,78,79)$. The rat shares with man the same type of haemochorial placenta, but rat pups are born at a more immature stage of brain development than the human baby. Morphological changes in the cortex have been studied in rats with adult-onset ID $^{80}$, as well as in the progeny of iodine deficient rat dams, mostly at different post-natal ages. The experimental designs did not permit the identification of alterations that could be unequivocally related to early maternal hypothyroxinemia alone, as they were mostly caused by the combined effect of maternal hypothyroxinemia with later foetal and postnatal cerebral hypothyroidism ${ }^{2,81,82}$. Among the investigations that were most closely related to possible effects on the brain of early ID and ensuing maternal hypothyroxinemia are the pioneering studies of McIntosh et al. $^{83}$, who obtained data on rat pups at birth. They fed rat dams with an iodine deficient diet that resulted in very low concentrations of circulating $\mathrm{T}_{4}$, but the rats maintained normal weight gain and reproductive efficiency when compared with animals on the same diet that had been supplemented with KI. This was an important improvement with respect to previous studies of the effects of ID. After confirming the iodine deficiency, the dams were mated and the pups were killed at birth and at 21 days post-natally. At birth the body weight and brain weight, the whole brain cholesterol concentration, and the DNA and protein contents were still normal, although some relatively small changes were found at 21 days after birth in cerebellar weight, cerebellar and cerebral protein and cholesterol, whereas the total DNA content remained the same. At 21 days of age, cell size was decreased in the cerebellum and cerebral hemispheres, with a relative increase in cell numbers relative to weight. This study did not disclose changes that could be attributed unequivocally to early maternal hypothyroxinemia, but morphological studies that might have revealed more specific alterations were not performed.

Li et $a l .{ }^{84}$ also fed rats on an iodine deficient diet prepared with ingredients obtained from Jixian Village (Huachuan County, Heilongjiangan Province, China) where the prevalence of endemic cretinism was then $11 \%$. The controls received the same diet but with added KI. The serum $\mathrm{T}_{4}$ concentration of iodine deficient dams was $48 \%$ of the value of the controls, and their $\mathrm{T}_{3}$ concentration increased to $113 \%$, both of which are characteristic autoregulatory responses of the thyroid to a decreased availability of iodine. Although most of the morphological studies were performed on pups between the day of birth and 60 days of age, they also included the brains of foetuses obtained 16-20 days after conception. The findings after birth were concordant with those of McIntosh et al. ${ }^{83}$ : the cerebral and cerebellar histological findings showed that the density of brain cells was higher, and the mean neuron size was lower; the branches of the pyramidal cells were fewer and shorter and the formation of myelin was reduced; furthermore, disappearance of the cerebellar external granular layer was delayed, and Purkinje cell morphology was altered. Findings from both of these studies revealed changes in brain development similar to those described during the early post-natal period in hypothyroid pups from dams chronically fed on goitrogens.

More interesting for the aim of the present review are the observations of Li et al. on foetal brains ${ }^{84}$. No changes were observed at day 16 but at day 17 they described a decrease in the ratio between the thickness of the cerebral cortex and the thickness of the brain wall, whereas the percentage volume of the ventricular zone cells was increased. From day 18 up to 30 days after birth, the cerebral cortical cell density was higher in the iodine deficient progeny. As already pointed out for the findings of McIntosh et $a l^{83}$, the study of Li et $a l^{84}$ did not reveal effects that could be unequivocally attributed to early maternal hypothyroxinemia.

Recent experiments on rats, however, have shown that changes in maternal thyroid hormone availability during early stages of development, which are equivalent to the end of the first, and beginning of the second, trimester of human pregnancy, affect neurogenesis irreversibly. Two experimental models have been studied so far. One involved iodine-deficient rat dams ${ }^{85,86}$, the other involved rat dams treated for only 3 days with the goitrogen 2-mercapto-1-methyl-imidazole (MMI), a treatment that resulted in a transient and very mild degree of maternal thyroid hormone deficiency ${ }^{87}$. In both experiments the dams were hypothyroxinemic without being hypothyroid, either clinically or biochemically, during the period of very active neurogenesis and migration of radial neurons into the developing cerebral cortex and hippocampus. This process occurs during a period when the mother is the only source of thyroid hormone for the developing foetus. In the rat the secretion of iodothyronines by the foetal thyroid starts at 17.5 to 18 days after conception. The final location of those cells that had been generated during early periods of neurogenesis was determined in the young offspring of these dams. This was accomplished by labelling the cells with 5-bromo-2'-deoxyuridine (BrdU), injected into the dams between days 14 and 16 or 17 and 19 , when two major waves of radial migration of 
neurons into the somatosensory cortex are taking place ${ }^{88}$. Their final positioning and the cytoarchitecture of the barrel cortex were studied in pups 40 days after birth, when the different cerebral structures can be clearly identified. Figure 4 shows an example of BrdU immunoreactive cells in aberrant heterotopic positions in the 40-day old pups born to dams that were chronically fed on the low-iodine diet (LID). The radial migration of the BrdU-immunoreactive cells, most of, which were identified as neurons, was significantly affected, with neurons appearing in aberrant locations and in cortical and hippocampal layers inappropriate for their date of birth. The proportion of neurons reaching the outer layers of the somatosensory cortex was clearly decreased (Fig. 5). The alterations in the final location reached by both the cells formed between days 14 and 16 and those incorporating BrdU between days 17 and 19 did not correspond to a delay in the normal migratory pattern, as erroneously stated $^{89}$. Neurons formed on these dates are never found in such locations in pups from normal dams (or in those from KI-supplemented LID dams (LID + KI). Cytoarchitectural changes were also found in the hippocampus and barrel cortex of the primary somatosensory cortex, where layering was blurred and normal barrels were not observed. These alterations also indicate an irreversible derangement of the normal developmental pattern that could be distinctly traced back to the maternal status during a very early period of brain histogenesis and cytoarchitecture. It is very important to realise that the LID dams were hypothyroxinemic, and showed the preferential secretion of $\mathrm{T}_{3}$ over $\mathrm{T}_{4}$ that is characteristic of

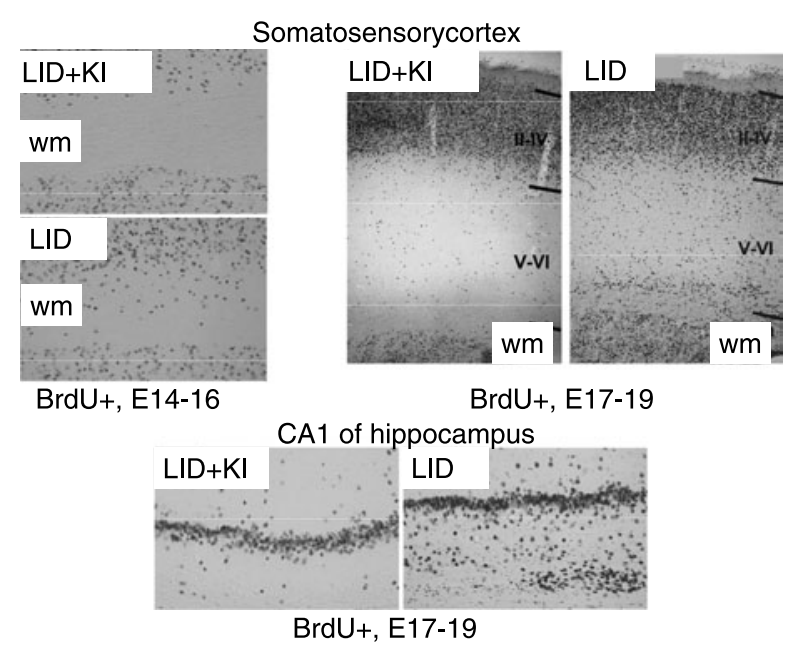

Fig. 4 Photomicrographs of coronal sections of primary somatosensory cortex and CA1 of hippocampus showing BrdU immunoreactive (BrdU+) cells in control (LID + KI) and LID pups at 40 days postnatal age. Examples are shown both for subgroups of dams injected with BrdU at days 14, 15, 16 post-conception $(\mathrm{BrdU}+, \mathrm{E} 14-16)$ and at days 17, 18, 19 (BrdU+, E17-19). The letters wm identifies the subcortical white matter. Unpublished photomicrographs from the study of Lavado-Autric et al. ${ }^{85}$. the autoregulatory responses of the thyroid to an ID. As described above for the inhabitants of iodine deficient areas, these animals were not 'clinically' hypothyroid as far as could be assessed from the normal reproductive competence of the dams (number of foetuses per litter and foetal weight), and the growth of their pups (normal body weight at 40-days of age) (Fig. 6 ).

The low iodine diet experiments did not permit a closer timing of the critical window during development when the foetal cortex is sensitive to maternal hypothyroxinemia, because it took several months of giving the diet for the dams to become hypothyroxinemic before being mated. We have attempted to define this period by using the 3 day MMI model ${ }^{87}$. Normal dams were treated with the goitrogen MMI for only 3 days, starting on the morning of day 12 after conception and stopping on the morning of day 15. The chemical label BrdU was injected into the dams between days 14 and 16 or 17 and 19, as in the LID experiment. Again, the brains of the pups were obtained at 40-days of age to study their cytoarchitecture. In $83 \%$ of the pups from the MMI-treated dams the same alterations were found, both in radial neuronal migration into the neocortex and hippocampus, as well as in cytoarchitecture of the barrel cortex, that had been observed in the progeny from LID dams. With the 3 day MMI protocol the maternal thyroid hormone deficiency was not only limited to a very precise window in development, but was also quite moderate: when the goitrogen was stopped the serum $T_{4}$ and $\mathrm{T}_{3}$ concentrations of dams were still approximately $70 \%$ of normal and the concentration of circulating TSH was not significantly higher than normal. Serum concentrations of $\mathrm{T}_{4}$ and $\mathrm{T}_{3}$ reverted to control values within a few days after stopping treatment with MMI. For the appearance of all of these abnormalities it was not necessary to maintain maternal hypothyroxinemia throughout pregnancy, as done using the LID, because the short period of maternal thyroid hormone deficiency created between days 12 and 15 after conception using MMI was sufficient not only to derange the radial migration of neurons formed between days 14 and 16, but also of those generated on days 17-19, after stopping the goitrogen. The cytoarchitecture of the hippocampus and barrel cortex also showed the same alterations as in the LID progeny. The infusion of $\mathrm{T}_{4}$ to correct the decrease in the maternal thyroid hormone concentration during the brief period of MMI treatment prevented the alterations of radial neuronal migrations and cytoarchitecture described above, whereas infusing $\mathrm{T}_{4}$ was of no benefit when delayed beyond the critical period of corticogenesis. An unexpected finding was the induction of behavioural alterations in a high proportion of the pups born to the MMI-treated dams. Figure 7 shows that a greater proportion of 40-days old pups showed a susceptibility to respond to acoustic stimulation with wild runs when compared with controls. Results obtained in these experimental studies are in conceptual agreement with 

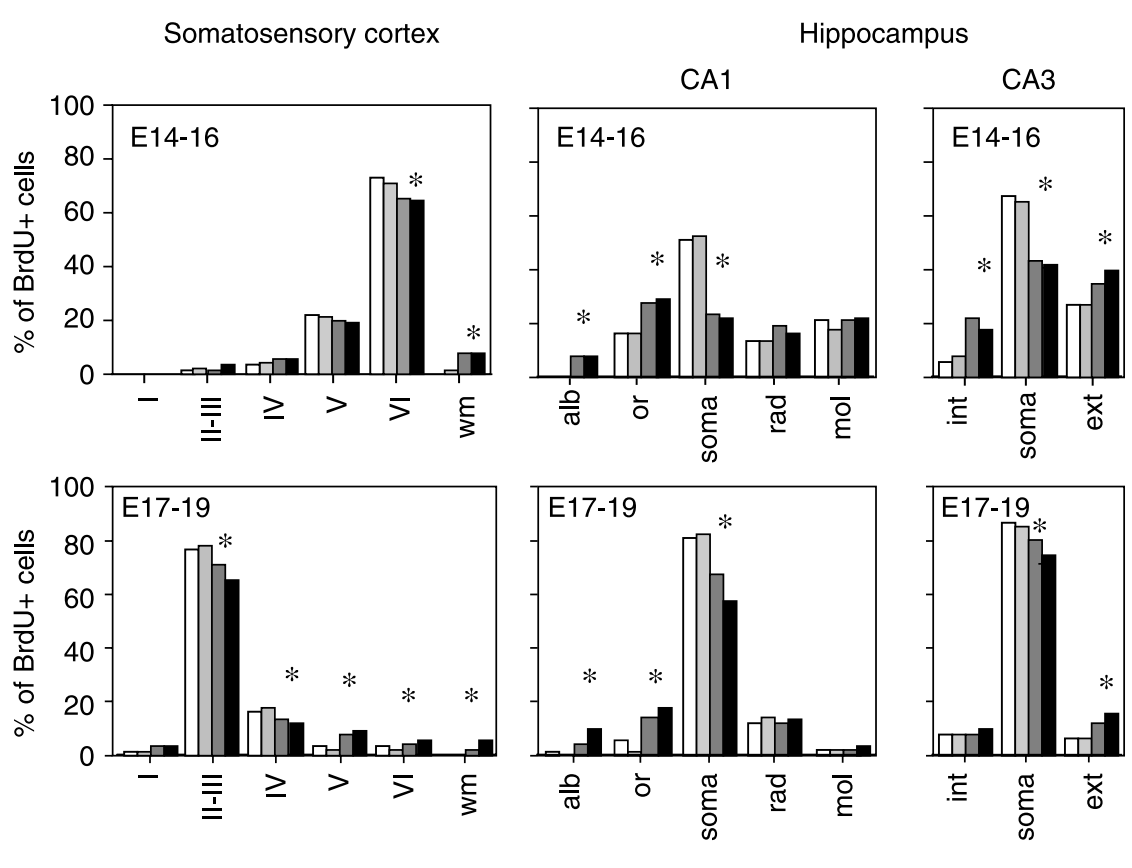

$\square$ Normal

$\square \mathrm{LID+KI}$

$\square$ LID-1

- LID-2

Fig. 5 The radial migration of the BrdU-immunoreactive (BrdU+) cells, most of, which were identified as neurons, was significantly affected by the maternal hypothyroxinemia caused by chronic ID in rats (LID model) ${ }^{85}$, with BrdU + cells appearing in aberrant locations and in cortical and hippocampal layers inappropriate for their date of birth. The proportion of neurons reaching the outer layers of the somatosensory cortex was clearly decreased, whereas the proportion of cells found in subcortical white matter (wm) increased. Alterations in the final location reached by the cells were observed both for those 'born' between 14 and 16 days post-conception (E14-16) and those incorporating BrdU between days 17 and 19 post-conception (E17-19). Layers I, II-III, IV, V and $\mathrm{VI}$ correspond to the somatosensory cortex, with wm corresponding to the subcortical white matter. The layers of the hippocampal CA1 and CA3 areas are stratum alveus (alb), stratum oriens (ori), stratum pyramidale (soma), stratum radiatum (rad), stratum moleculare (mol), inner plexiform stratum (int), stratum pyramidale (soma) and outer plexiform stratum (ext). Asterisks identify statistically significant differences between pups from both groups of LID dams, when compared with pups born to dams fed on LID + KI and to normal dams, fed on stock pellets.

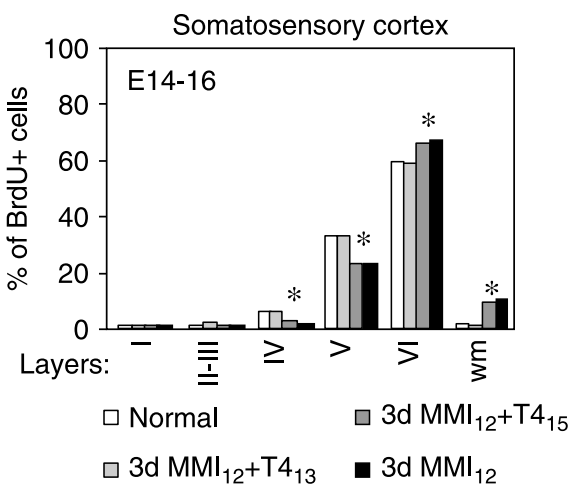

Fig. 6 Results obtained with the 3dMMl experimental model in rats. The histogram shows significant differences between the percentage of BrdU+ cells found in different layers of the somatosensory cortex and in subcortical white matter (wm) of 40 day-old pups born to normal rat dams and to dams treated for only 3 days with MMI, started 12 days post-conception withdrawn at 15 days post-conception ( $3 \mathrm{dMMI}_{12}$ group). The alterations in the migratory pattern of the BrdU+ cells (BrdU injected on days 14,15 and 16 post-conception (E14-16) were prevented when $T_{4}$ was infused during the phase of MMI treatment $\left(3 \mathrm{dMMI}_{12}+\mathrm{T}_{413}\right.$ group), but had become irreversible when the infusion was delayed beyond the critical window at the onset of corticogenesis (3dMMl $12+\mathrm{T}_{415}$ group). Results are from the study by Ausó et al. ${ }^{87}$. those recently reported by others ${ }^{86,90-92}$. The results from the two studies summarised above $e^{85,87}$ are the first to confirm the irreversibility of the early brain damage related to maternal hypothyroxinemia. We believe that the implications for humans regarding the possible damaging effects of early maternal hypothyroxinemia on neurodevelopment are supported by the observation in human foetal brains from an area where ID is endemic of an increased proportion of heterotopic neurons in locations different from their 'assigned' layers ${ }^{67}$.

\section{Conclusions}

Early in pregnancy the conceptus imposes important changes on maternal thyroid hormone requirements that result in an increased pool of circulating $\mathrm{fT}_{4}$, with a surge early during the first trimester of pregnancy. This surge is proposed as a biologically relevant event controlled by the conceptus to ensure that its developing cerebral cortex is provided with enough substrate to generate adequate amounts of $\mathrm{T}_{3}$ to bind to its nuclear receptors, and results in biological effects. During this period TSH secretion is suppressed and circulating TSH is not necessarily 

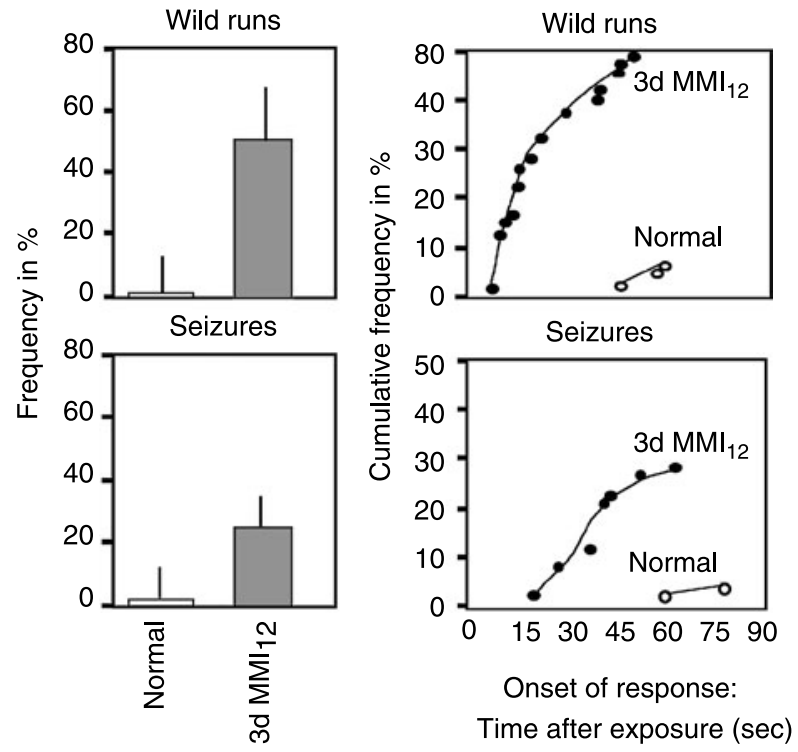

Fig. 7 Results obtained with the 3dMMl experimental model in rats. The percentage of pups responding to an acoustic stimulus with 'wild runs' is markedly increased in the progeny of the $3 \mathrm{dMMI}_{12}$ dams when compared with pups born to normal dams (left upper panel). In some of these pups, the 'wild run' was followed by a clonic-tonic seizure (left lower panel). Panels on the right represent the cumulative frequency of pups from the same groups that responded with wild runs (upper panel) or wild runs followed by seizures (lower panel) at the intervals after onset of the acoustic stimulus that are shown in the abscissa. The asterisks indicate significant differences between groups of pups. Rat pups were exposed to $95-100 \mathrm{~dB}$ for a maximum of $90 \mathrm{~s}$. The acoustic challenge was interrupted sooner if the animal responded with a seizure. Results are from the study by Ausó et al. ${ }^{87}$.

increased above the normal range in cases when there is an inadequate first trimester $\mathrm{fT}_{4}$ surge.

Women who are unable to increase their production of $\mathrm{T}_{4}$ early in pregnancy would constitute a population at risk for neurological disabilities in their children. This conclusion is strongly supported by experimental evidence in rats that shows that even a moderate and transient period of maternal thyroid hormone insufficiency during periods of active neocorticogenesis irreversibly affects cortical and hippocampal cytoarchitecture, with neurons reaching heterotopic locations. As a mild to moderate ID is still the most widespread cause of maternal hypothyroxinemia in Western societies, the birth of many children with learning disabilities may be prevented by advising women to take iodine supplements as soon as pregnancy starts, or earlier if possible.

It would appear that a daily iodine intake resulting in a urinary iodine concentration of approximately 180$200 \mu \mathrm{gl}^{-1}$ is the minimum needed to avoid blunting of the early serum $\mathrm{fT}_{4}$ surge. This requires an intake of approximately $250-300 \mu \mathrm{g}$ of iodine a day, which is in agreement with other recent estimates ${ }^{5,44}$.

It follows that the learning disabilities of future generations can be prevented by promoting the following: the universal use of iodised salt throughout life; the use of iodine supplements, both as vitamin-mineral mixtures that contain KI, or as KI tablets, whenever available, from the onset of pregnancy (or earlier if pregnancy is planned), just as folate supplements are extensively promoted for pregnant women without prior confirmation of a folate deficiency.

\section{Additional remarks regarding human ID}

As indicated in the introduction, in the present review we have not considered the likely further increase in iodine requirements in those places where ID is not the only nutritional condition that affects thyroid function, as occurs in areas where myxoedematous, or mixed type, cretinism is predominant ${ }^{60,93,94}$. Factors such as goitrogens in food, selenium deficiency and endocrine disruptors, impair the response of the thyroid through autoregulatory mechanisms; both circulating $\mathrm{T}_{4}$ and $\mathrm{T}_{3}$ are then insufficient, and the offspring are increasingly hypothyroid. Prevention of IDD in such areas may well require additional intervention strategies.

We also have not reviewed the evidence that maternal hypothyroxinemia early in pregnancy and unrelated to an ID also affects neurodevelopment of the offspring ${ }^{95,96}$ further increasing the frequency of learning disabilities in children born in developed societies. Such handicaps might be prevented if early maternal hypothyroxinemia were detected and corrected. ID, however, still remains the major cause of such disabilities worldwide, including industrialised societies ${ }^{97}$.

Because of the frequency with which some observations are incorrectly interpreted, we wish to emphasise here two important examples, already referred to above.

First, the regulation of thyroid function through the hypothalamic-pituitary-thyroid negative feedback loop is so ingrained in our thinking that in clinical practice a low circulating $\mathrm{T}_{4}$ concentration is automatically associated with a high TSH concentration, and with hypothyroidism, either clinical or subclinical. Only when there is evidence that TSH is not increased is the individual patient studied for evidence of causes other than primary thyroid failure. Thus, the definition of 'hypothyroxinemia', namely that the concentration of $\mathrm{T}_{4}$ or $\mathrm{fT}_{4}$ has decreased without an increase in the concentration of TSH above the normal reference range is intuitively rejected. Moreover, very efficient mechanisms controlling thyroid function other than the negative feedback loop are overlooked or, very frequently, poorly known to most physicians, who associate them with iodine overload, but not with ID. Because of this widespread assumption, statements referring to increases in the TSH concentration in otherwise healthy iodine deficient pregnant women should always indicate that they occur within the normal reference range ${ }^{40,43}$. As this is not always the case, when a circulating TSH concentration above the reference range is not found, it is wrongly concluded that the women are not 
iodine-deficient, and the possibility that their iodine intake is inadequate for pregnancy and lactation is overlooked.

Second, and equally dangerous, is the reliance on changes in foetal and cord serum TSH values as indicators of foetal thyroid hormone status. The high foetal TSH concentrations reported by Thorpe-Beeston et $a .^{27}$ and later observed by $\mathrm{us}^{25}$ had already been described by Fisher et $a l .{ }^{98}$, who reported mean values of 9.6 (SD 0.93) $\mathrm{mIUl}^{-1}$ at 22-34 weeks of gestation, and 8.9 (SD 0.93) $\mathrm{mIUl}^{-1}$ at $38-40$ weeks. Such values have also been confirmed quite recently by the analysis of results from a database of 695 cord serum TSH values obtained from premature and full term neonates, grouped by gestational age at birth ${ }^{99}:$ mean values ranged between 6.7 (SD 4.8) to 7.9 (SD 5.2) $\mathrm{mIUl}^{-1}$. The individual values were likely to be positively correlated with the $\mathrm{fT}_{4}$ concentration, because the $\mathrm{TSH} / \mathrm{fT}_{4}$ ratio was constant. The negative correlation that would be expected if the TSH levels were regulated through the hypothalamic-pituitary-thyroid feedback loop was definitely excluded (personal communication by the authors).

Foetal TSH that is not under hypothalamic control has a very high bioactivity and is very poorly sialylated ${ }^{100}$. Contrary to our previous (and mistaken) statements regarding the possible extrahypophyseal site of synthesis of this $\mathrm{TSH}^{10,101}$, which were prompted by the high concentrations found in foetal serum before full maturation of hypothalamic-pituitary vascular connections at mid-gestation, it has now been definitely established that the TSH circulating in the normal foetus is secreted by the foetal pituitary gland as it is undetectable in the serum of foetuses in whom the hypophysis is absent ${ }^{102}$. Circulating TSH contains isoforms that differ in the degree of sialylination of the carbohydrate chains that modify their biological potency ${ }^{100}$. The TSH circulating predominantly in the serum of a normal foetus is of an isoform with a high biological/immunological (B/I) ratio, and its secretion is independent of hypothalamic control ${ }^{28,29}$. But the foetal pituitary also secretes a highly sialylated TSH isoform with a lower $\mathrm{B} / \mathrm{I}$ that is under hypothalamic-pituitary negative feedback control. This isoform predominates in the circulation of foetuses with primary hypothyroidism, as well as in normal and hypothyroid adults, including pregnant women ${ }^{100}$. The hypothalamic-pituitary negative feedback control of the secretion of this TSH isoform is already operative in the foetus by mid-gestation, as demonstrated by cases of intrauterine diagnosis and treatment of congenital primary hypothyroidism, based on elevated levels of foetal serum TSH. These concentrations decreased with interventions correcting the hypothyroid condition of the foetus ${ }^{103,104}$. In all reported cases of foetal primary hypothyroidism, the concentration of TSH was much higher than $12 \mathrm{mIUl}^{-1}$, and well above the threshold values used in neonatal thyroid screening of $\geq 25 \mathrm{mIUl}^{-1}$. Thus, it now appears that cord serum TSH concentrations up to $12-14 \mathrm{mIUl}^{-1}$ are normal, they are not under hypothalamic control, they are positively correlated with the foetal $\mathrm{fT}_{4}$ concentration, and should not be used to assess foetal thyroid status. These values, moreover, appear to be influenced by perinatal stress ${ }^{105}$. Much higher values, in the region of the threshold used in neonatal screening programs of $\geq 25 \mathrm{mIUl}^{-1}$, are to be expected when TSH secretion is responding to changes in thyroid hormone availability through hypothalamicpituitary negative feedback control.

When cord blood or neonatal screening TSH concentrations are used as criteria to define the degree of ID in a locality ${ }^{62}$, values below $5 \mathrm{mIUl}^{-1}$ whole blood, which are equivalent to approximately $10 \mathrm{mIUl}^{-1}$ of serum, are considered normal: an ID is suspected when higher concentrations are found in more than $3 \%$ of newborns. In a large survey in northern China ${ }^{106}$ adverse effects on the neurodevelopment of children were found in the group of newborns with a cord blood TSH concentration above this threshold, and mainly in the groups of children with levels above $20 \mathrm{mIUl}^{-1}$ serum. Changes in the cord blood TSH concentration, from a median of $7.07 \mathrm{mIUl}^{-1}$ to $9.00 \mathrm{mIUl}^{-1}$ in infants born to women with mild-moderate ID, who had received a daily supplement of $150 \mu \mathrm{g}$ I, as compared with infants from non-supplemented mothers, have been interpreted as evidence of undesirable and potentially harmful effects of maternal iodine supplementation for the child ${ }^{107}$. However, the data actually showed an improvement in foetal thyroid status when mothers were given iodine supplements, because cord blood $\mathrm{fT}_{4}$ increased in concentration, and $\mathrm{Tg}$ concentration decreased. The observed increase in cord serum TSH concentration is actually the expected change, considering that there is a positive correlation between the foetal TSH concentration and $\mathrm{fT}_{4}$. It should not be interpreted as indicating a potentially harmful effect of iodine supplement on the mother. If, as discussed above, this foetal TSH is acting as a growth factor for the brain ${ }^{32,33}$, the observed increase might actually be a beneficial consequence of maternal iodine supplementation during pregnancy. Continuing reference to the above study ${ }^{107}$ as evidence against iodine supplementation during pregnancy should be avoided, because the evidence is likely to be an incorrect interpretation of physiological changes in cord serum TSH concentrations.

\section{Acknowledgement}

We are grateful for the financial support of grants from Instituto de Salud Carlos III. RCMN (03/08) and FIS PI03/1417 of Spain, to GME.

\section{References}

1 Jonsson U. Nutrition and the convention on the rights of the child. Food Policy 1996; 21: 41-55. 
2 Hetzel BS, Chavadej J, Potter BJ. The brain in iodine deficiency. Neuropatbology and Applied Neurobiology 1988; 14: 93-104.

3 Hetzel BS. Historical development of concepts of brainthyroid relationships. In: Stanbury JB, ed. The Damaged Brain of Iodine Deficiency. Elmsford, New York: Cognizant Communication, 1994; 1-8.

4 Delange F. Iodine deficiency as a cause of brain damage. Postgraduate Medical Journal 2001; 77: 217-20.

5 Delange F, Lecomte P. Iodine supplementation: benefits outweigh risks. Drug Safety 2000; 22: 89-95.

6 Glinoer D, Delange F. The potential repercussions of maternal, fetal, and neonatal hypothyroxinemia on the progeny. Thyroid 2000; 10: 871-7.

7 Morreale de Escobar G, Obregón MJ, Calvo R, Pedraza PE, Escobar del Rey F. Iodine deficiency, the hidden scourge: the rat model of human neurological cretinism. In: Hendrich $\mathrm{CH}$, ed. Neuroendocrinology. Trivandrum, India: Research Signpost and Scientific Information Guild, 1997; 55-70.

8 Morreale de Escobar G, Obregón MJ, Escobar del Rey F. Is neuropsychological development related to maternal hypothyroidism, or to maternal hypothyroxinemia? Journal of Clinical Endocrinology and Metabolism 2000; 85 3975-87.

9 Morreale de Escobar G, Escobar del Rey F. Consequences of iodine deficiency for brain development. In: deVijlder J, Morreale de Escobar G, eds. The Thyroid and the Brain. Stuttgart: Schattauer Verlag, 2003; 33-56.

10 Morreale de Escobar G, Obregón MJ, Escobar del Rey F. Role of thyroid hormone during early brain development. European Journal of Endocrinology 2004; 151: U25-U37.

11 Choufoer JC, van Rhijn M, Querido A. Endemic goiter in Western New Guinea. II. Clinical picture, incidence and pathogenesis of endemic cretinism. Journal of Clinical Endocrinology and Metabolism 1965; 25: 385-402.

12 Pharoah POD, Ellis SM, Ekins RP, Williams ES. Maternal thyroid function, iodine deficiency and fetal development. Clinical Endocrinology (Oxford) 1976; 5: 159-66.

13 Pretell EA, Stanbury JB. Effect of chronic iodine deficiency on maternal and fetal thyroid hormone synthesis. In: Hetzel BS, Pharoah POD, eds. Endemic Cretinism. Papua New Guinea Institute of Medical Research Monograph Series, No 2. Goroka: Institute of Human Biology, 1971; 117-24.

14 Pretell EA, Cáceres A. Impairment of mental development by iodine deficiency and its correction. A retrospective view from studies in Peru. In: Stanbury JB, ed. The Damaged Brain of Iodine Deficiency. Elmsford, New York: Cognizant Communication, 1994; 187-92.

15 Pharoah POD, Buttfield IH, Hetzel BS. Neurological damage to the fetus resulting from severe iodine deficiency during pregnancy. Lancet 1971; 1: 308-11.

16 Xue-Yi C, Xin-Min J, Zhi-Jong D, Rakeman MA, Ming-Li Z, O'Donnell K, et al. Timing of vulnerability of the brain to iodine deficiency in endemic cretinism. New England Journal of Medicine 1994; 331: 1739-44.

17 Connolly KJ, Pharoah POD, Hetzel BS. Fetal iodine deficiency and motor performance during childhood. Lancet 1979; 1: 1149-51.

18 Pharoah POD, Connolly K, Hetzel B, Ekins R. Maternal thyroid function and motor competence in the child. Developmental Medicine and Child Neurology 1981; 23: 76-82

19 Pharoah POD, Connolly KJ, Ekins RP, Harding AG. Maternal thyroid hormone levels in pregnancy and the subsequent cognitive and motor performance of the children. Clinical Endocrinology (Oxford) 1984; 21: 265-70.

20 Pharoah POD, Connolly KJ. Relationship between maternal thyroxine levels during pregnancy and memory function in childhood. Early Human Development 1991; 25: 43-51.
21 Bleichrodt N, Bjorn M. A metaanalysis of research on iodine and its relationship to cognitive development. In: Stanbury JB, ed. The Damaged Brain of Iodine Deficiency. Elmsford, New York: Cognizant Communication, 1994; 195-200.

22 Vitti P, Aghini-Lombardi F, Chiovato L, Ferretti G, Pinchera A. Neuropsychological assessment in humans living in mild to moderate iodine deficiency. In: DeVijlder J, Morreale de Escobar G, eds. The Thyroid and the Brain. Stuttgart: Schattauer Verlag, 2003; 57-63.

23 Vermiglio F, Lo Presti VP, Moleti M, Sidoti M, Tortorella G, Scaffidi G, et al. Attention deficit and hyperactivity disorders (ADHD) in the offspring of mothers exposed to iodine deficiency: a possible novel iodine deficiency disorder in developed countries? Journal of Clinical Endocrinology and Metabolism 2004; 89: 6054-60.

24 Contempré B, Jauniaux E, Calvo R, Jurkovic D, Campbell S, Morreale de Escobar G. Detection of thyroid hormones in human embryonic cavities during the first trimester of pregnancy. Journal of Clinical Endocrinology and Metabolism 1993; 77: 1719-22.

25 Calvo RM, Jauniaux E, Gulbis B, Asunción M, Gervy C, Contempré B, et al. Fetal tissues are exposed to biologically relevant free thyroxine concentrations during early phases of development. Possible consequences of maternal hypothyroxinemia. Journal of Clinical Endocrinology and Metabolism 2002; 87: 1768-77.

26 Anselmo J, Cao D, Karrison T, Weiss RE, Refetoff S. Fetal loss associated with excess thyroid hormone exposure. Journal of the American Medical Association 2004; 292: 691-5.

27 Thorpe-Beeston JG, Nicolaides KH, Felton CV, Butler J, McGregor AM. Maturation of the secretion of thyroid hormone and thyroid-stimulating hormone in the fetus. New England Journal of Medicine 1991; 324: 532-6.

28 Grasso S, Filetti S, Mazzon D, Pezzino V, Vigo R, Vigneri R. Thyroid-pituitary function in eight anencephalic infants. Acta Endocrinologica (Copenhagen) 1980; 93: 396-401.

29 Beck-Peccoz P, Cortelazzi D, Persani L, Papandreou MJ, Asteria C, Borgato S, et al. Maturation of pituitary-thyroid function in the anencephalic fetus. Acta Medica Austriaca 1992; 19(Suppl. 1): 72-6.

30 Morine M, Takeda T, Minekawa R, Sugiyama T, Wasada K, Mizutani T, et al. Antenatal diagnosis and treatment of a case of fetal goitrous hypothyroidism associated with highoutput cardiac failure. Ultrasound in Obstetrics and Gynecology 2002; 19: 506-9.

31 Crisanti P, Omri B, Hughes EJ, Meduri G, Hery C, Clauser E, et al. The expression of thyrotropin receptor in the brain. Endocrinology 2001; 142: 812-22.

32 Saunier B, Pierre M, Jacquemin C, Courtin F. Evidence for cAMP-independent thyrotropin effects on astroglial cells. European Journal of Biochemistry 1993; 218: 1091-4.

33 Szkudlinski MW, Fremont V, Ronin C, Weintraub BD. Thyroid stimulating hormone and thyroid stimulating hormone receptor structure-function relationships. Physiological Reviews 2002; 82: 473-502.

34 Bernal J, Pekonen F. Ontogenesis of the nuclear 3,5, $3^{\prime}$ triiodothyroxine receptor in the human fetal brain. Endocrinology 1984; 114: 677-9.

35 Ferreiro B, Bernal J, Goodyer CG, Branchard CL. Estimation of nuclear thyroid hormone receptor saturation in human fetal brain and lung during early gestation. Journal of Clinical Endocrinology and Metabolism 1988; 67: 853-6.

36 Iskaros J, Pickard M, Evans I, Sinha A, Hardiman P, Ekins R. Thyroid hormone receptor gene expression in first trimester human fetal brain. Journal of Clinical Endocrinology and Metabolism 2000; 85: 2620-3.

37 Lazar MA. Thyroid hormone receptors: multiple forms, multiple possibilities. Endocrine Reviews 1993; 14: $184-93$. 
38 Kester M-HA, Martinez de Mena R, Obregon MJ, Marinkovic D, Howatson A, Visser TH, et al. Iodothyronine levels in the human developing brain: major regulatory roles of iodothyronine deiodinases in different areas. Journal of Clinical Endocrinology and Metabolism 2004; 89: 3117-28.

39 Calvo R, Obregon MJ, Ruiz de Oña C, Escobar del Rey F, Morreale de Escobar G, et al. Congenital hypothyroidism, as studied in rats. Crucial role of maternal thyroxine but not of $3,5,3^{\prime}$-triiodothyronine in the protection of the fetal brain. Journal of Clinical Investigation 1990; 86: 889-99.

40 Glinoer $D$. The regulation of thyroid function in pregnancy: pathways of endocrine adaptation from physiology to pathology. Endocrine Reviews 1997; 18: 404-33.

41 Anselmo J, Kay T, Dennis S, Szmulewitz R, Refetoff S, Weiss RE. Resistance to thyroid hormone does not abrogate the transient thyrotoxicosis associated with gestation: report of a case. Journal of Clinical Endocrinology and Metabolism 2001; 86: 4273-5.

42 Wasco EC, Martinez E, Grant KS, StGermain DI, Galton VA. Determinants of iodothyronine deiodinase activities in rodent uterus. Endocrinology 2003; 144: 4253-61.

43 Glinoer D. Regulation of thyroid function during normal pregnancy: importance of the iodine nutrition status. Best Practice and Research in Clinical Endocrinology and Metabolism 2004; 18: 133-52.

44 Mandel SJ. Hypothyroidism and chronic autoimmune thyroiditis in the pregnant state: maternal aspects. Best Practice and Research in Clinical Endocrinology and Metabolism 2004; 18: 213-24.

45 Mandel SJ, Larsen PR, Seely EW, Brent GA. Increased need for thyroxine during pregnancy in women with primary hypothyroidism. New England Journal of Medicine 1990; 232: 91-6.

46 Alexander EK, Marqusee E, Lawrence J, Jarolim P, Fischer GA, Larsen PR. Timing and magnitude of increases in levothyroxine requirements during pregnancy in women with hypothyroidism. New England Journal of Medicine 2004; 351: 241-9

47 Delange F. Optimal iodine nutrition during pregnancy, lactation and the neonatal period. International Journal of Endocrinology and Metabolism 2004; 2: 1-12.

48 de Santiago J, Pastor I, Escobar del Rey F, Morreale de Escobar G. Thyroid function in pregnant women from an area with mild (Grade I) iodine deficiency. Journal of Endocrinological Investigation 1999; 22(Suppl. 6, Abstract 126): 68 .

49 Escobar del Rey F, Lavado Autric R, Vázquez JA, Morreale de Escobar G. Are all criteria defining degrees of iodine deficiency adequate to assess eradication of Iodine Deficiency Disdorders?. In: Sánchez-Franco F, Wass J, eds. IV European Congress of Endocrinology, 1998 . Sevilla, Spain: BioScientifica, 1998.

50 Barnett CA, Visser TJ, Williams F, van Toor H, Durán S, Presas MJ, et al. Inadequate iodine intake of $40 \%$ of pregnant women from a region in Scotland. In: 28th Annual meeting of the European Thyroid Association, 2002, Göteborg, Sweden. Journal of Endocrinological Investigation 2002; 25(Suppl. 7, Abstract P110): 90.

51 Escobar del Rey F, Sánchez-Vega J, Morreale de Escobar G. Informe sobre el estudio epidemiológico de la nutrición en yodo de mujeres embarazadas de Extremadura. Sent to Local Health Authorities 2004: unpublished.

52 Domínguez I, Reviriego S, Rojo-Martínez G, Valdés JM, Carrasco R, Coronas I, et al. Déficit de yodo y función tiroidea en una población de mujeres embarazadas sanas. Medicina Clínica (Barcelona) 2004; 122: 449-53.

53 Halmi NS, Spirtos BN. Analysis of the modifying effect of dietary iodine levels on the thyroidal response of hypophysectomized rats to thyrotropin. Endocrinology 1955; 56: 157-60.
54 Greer MA. Qualitative changes in the secretion of thyroid hormones induced by iodine deficiency. Endocrinology 1968; 83: 1193-8.

55 Arntzenius AB, Smit LJ, Schipper J, van der Heide D, Meinders AE. Inverse relation between iodine intake and thyroid blood flow: color Doppler flow imaging in euthyroid humans. Journal of Clinical Endocrinology and Metabolism 1991; 73: 1051-5.

56 Pisarev MA. Thyroid autoregulation. Journal of Endocrinological Investigation 1985; 8: 475-84

57 Pharoah POD, Lawton NF, Ellis SM, Williams ES, Ekins RP. The role of triiodothyronine in the maintenance of euthyroidism in endemic goitre. Clinical Endocrinology (Oxford) 1973; 2: 193-9.

58 Vagenakis A, Koutras D, Burger A, Malamos B, Ingbar S. Studies of serum triiodothyronine, thyroxine and thyrotropin concentrations in endemic goiter in Greece. Journal of Clinical Endocrinology and Metabolism 1973; 37: 485-8.

59 Missler U, Gutekunst R, Wood WG. Thyroglobulin is a more sensitive indicator of iodine deficiency than thyrotropin: development and evaluation of dry blood spot assays for thyrotropin and thyroglobulin in iodine-deficient geographical areas. European Journal of Clinical Chemistry and Clinical Biochemistry 1994; 32: 137-43.

60 Dumont JE, Corvilain B, Contempré B. Endemic cretinism: the myxoedematous and neurological forms of the disease caused by severe iodine deficiency. In: Stanbury JB, ed. The Damaged Brain of Iodine Deficiency. Elmsford, New York: Cognizant Communication, 1994; 195-200.

61 Delange F, Bourdoux P, Ermans AM. Transient disorders of thyroid function and regulation in preterm infants. In: Delange F, Fisher DA, Malvoux P, eds. Pediatric Thyroidology. Basel: S Karger AG, 1985; 369-93.

62 World Health Organization. Assessment of Iodine Deficiency Disorders and Monitoring their Elimination, 2 ed. Geneva, Switzerland: Department of Nutrition, World Health Organization, 2001.

63 Yan YQ, Guan C, Leng L, LI JQ. Quantitative histology study on brain nervous cells of neurological endemic cretins. In: Delong GR, Robbins J, Condliffe PG, eds. Iodine and the Brain. New York: Plenum Publishing Corporation, 1989; 359 .

64 Cruz M, Cavelos P, Uteras A, Malo L. Gina de tomografía axial computerizada. Quito, Ecuador, 1984.

65 Ma T, Lian ZC, R HE, DeLong GR. Magnetic resonance imaging of the brain and the neuromotor deficit in endemic cretinism. Annals of Neurology 1993; 34: 91-4.

66 DeLong GR, Tai M, Xue-ui C, Xin-Min J, Zhi-hong D, Rakeman MA, et al. The neuromotor deficit in endemic cretinism. In: Stanbury JB, ed. The Damaged Brain of Iodine Deficiency. Elmsford, NY: Cognizant Communication Co, 1994; 9-14.

67 Jia-Liu L, Zhong-Jie S, Zhon-Fu S, Jia-Xiu Z, Yu-Bin T, BingZhong C. Influence of iodine deficiency on human fetal thyroid gland and brain. In: Delong GR, Robbins J, Condliffe PG, eds. Iodine and the Brain. New York: Plenum Publishing Corporation, 1989; 249-58.

68 Jia-Liu L, Zhong-Jie S, Yu-Bin T, Zhon-Fu S, Xi-tian L, Xiubao $\mathrm{Y}$, et al. Morphologic study on cerebral cortex development in therapeutically aborted fetuses in an endemic goiter region in Guizhou. Chinese Medical Journal (English) 1984; 97: 67-72.

69 Jia-Liu L, Zhong-Jie S, Xu-mao C, Shang-an L, Fu-guang Z, Zhong-guo G, et al. Changes in thyroid, cerebral cortex and bones of therapeutically aborted fetuses from endemic goiter region supplied with iodized salt for 5 years. Chinese Medical Journal (English) 1988; 101: 133-6.

70 Potter BJ, Jones GB, Buckley RA, Belling GB, Mcintosh GH, Hetzel BS. Production of severe iodine deficiency in sheep 
using a prepared low-iodine diet. Australian Journal of Biological Sciences 1980; 33: 53-61.

71 Hetzel BS. Hormone nurturing of the developing brain: Sheep and Marmoset models. In: Stanbury JB, ed. The Damaged Brain of Iodine Deficiency. Elmsford, New York: Cognizant Communication, 1994; 123-30.

72 Potter BJ, Mano MT, Belling GB, Mcintosh GH, Hua C, Cragg BG, et al. Retarded fetal brain development resulting from severe dietary iodine deficiency in sheep. Neuropathology and Applied Neurobiology 1982; 8: 303-13.

73 McIntosh GH, Baghurst KI, Potter BJ, Hetzel BS. Foetal thyroidectomy and brain development in the sheep. Neuropathology and Applied Neurobiology 1979; 5: 363-76.

74 Potter BJ, Mano MT, Belling GB, Martin DM, Cragg BG, Chavadej J, et al. Restoration of brain growth in fetal sheep after iodized oil administration to pregnant iodine-deficient ewes. Journal of Neurological Sciences 1984; 66: 15-26.

75 Hetzel BS, Potter B. Iodine deficiency and the role of thyroid hormones in brain development. In: Dreosti IE, Smith RM, eds. Neurobiology of the Trace Elements. Totawa, NJ: Humana Press, 1983; 83-133.

76 Mano MT, Potter BJ, Belling GB, Hetzel BS. Low-iodine diet for the production of severe iodine deficiency in marmosets (Callithrix jacchus jacchus). British Journal of Nutrition 1985; 54: 367-73

77 Mano MT, Potter BJ, Belling GB, Chavadej J, Hetzel BS. Fetal brain development in response to iodine deficiency in a primate model (Callithrix Jacchus Jacchus). Journal of Neurological Sciences 1987; 79: 287-300.

78 Morreale de Escobar G, Ruiz de Oña C, Obregon MJ, Escobar del Rey F. Models in fetal iodine deficiency. In: Delong GR, Robbins J, Condliffe PG, eds. Iodine and the Brain. New York: Plenum Publishing Corporation, 1989; 187-201.

79 Morreale de Escobar G, Obregón MJ, Calvo R, Escobar del Rey F. Hormone nurturing of the developing brain: the rat model. In: Stanbury JB, ed. The Damaged Brain in Iodine Deficiency. Elmsford, New York: Cognizant Communication Co, 1994; 103-22.

80 Obregón MJ, Santisteban P, Rodriguez-Peña A, Pascual A, Cartagena P, Ruiz-Marcos A, et al. Cerebral hypothyroidism in rats with adult-onset iodine deficiency. Endocrinology 1984; 115: 614-24.

81 Chen ZP, Chen XX, Zhu XL, Dong L, Hu X, Zhao WD, et al. The iodine deficient rat. In: Medeiros-Neto G, Maciel RMB, Halpern A, eds. Iodine Deficiency Diseases and Congenital Hypothyroidism. Sao Paulo: Aché Press, 1986; 46-51.

82 Martinez-Galan JR, Pedraza P, Santacana M, Escobar del Rey F, Morreale de Escobar G, Ruiz Marcos A. Early effects of iodine deficiency on radial glial cells of the hippocampus of the rat fetus a model of neurological cretinism. Journal of Clinical Investigation 1997; 99: 2701-9.

83 McIntosh GH, Howard DA, Mano MT, Wellby ML, Hetzel BS. Iodine deficiency and brain development in the rat. Australian Journal of Biological Sciences 1981; 34: 427-33.

84 Li JQ, Wang X, Yan YQ, Wang KW, Qin DK, Xin ZF, et al. The effects on fetal brain development in the rat of a severely iodined deficient diet derived from an endemic area: observations on the first generation. Neuropatbology and Applied Neurobiology 1986; 12: 261-76.

85 Lavado-Autric R, Ausó E, García-Velasco JV, Arufe MC, Escobar del Rey F, Berbel P, et al. Early maternal hypothyroxinemia alters histogenesis and cerebral cortex cytoarchitecture of the progeny. Journal of Clinical Investigation 2003; 111: 1073-82.

86 Zoeller RT. Transplacental thyroxine and fetal brain development. Journal of Clinical Investigation 2003; 111: $954-7$.
87 Ausó E, Lavado-Autric R, Cuevas E, Escobar del Rey F, Morreale de Escobar G, Berbel P, et al. A moderate and transient deficiency of maternal thyroid function at the beginning of fetal neocorticogenesis alters neuronal migration. Endocrinology 2004; 145: 4037-47.

88 Bayer SA, Altman J. Neocortical Development. New York: Raven Press, 1991.

89 Forrest D. The developing brain and maternal thyroid hormone: finding the links. Endocrinology 2004; 149: 4034-6.

90 Dowling ALS, Zoeller RT. Thyroid hormone of maternal origin regulates the expression of RC3/neurogranin mRNA in the fetal rat brain. Brain Research Molecular Brain Research 2000; 82: 126-32.

91 Dowling ALS, Iannacone EA, Zoeller RT. Maternal hypothyroidism selectively affects the expression of neuroendocrine-specific protein A messenger ribonucleic acid in the proliferative zone of the fetal rat brain cortex. Endocrinology 2001; 142: 390-9.

92 Dowling ALS, Martz GU, Leonard JL, Zoeller RT. Acute changes in maternal thyroid hormone induce rapid and transient changes in gene expression in fetal rat brain. Journal of Neuroscience 2000; 20: 2255-65.

93 Vanderpas J, Thilly $\mathrm{CH}$. Endemic neonatal, infantile and juvenile hypothyroidism in Ubangi, Northern Zaïre: clinical consequences and prevention. In: Stanbury JB, ed. The Damaged Brain of Iodine Deficiency. Elmsford, New York: Cognizant Communication, 1994; 209-24.

94 Contempré B, Morreale de Escobar G, Denef JF, Dumont JE, Many MC. Thiocyanate induces cell necrosis and and fibrosis in selenium- and Iodine-deficient rat thyroids: a potential expedrimental model for myxedematous endemic cretinism in central Africa. Endocrinology 2004; 145: 994-1002.

95 Pop V, Kuipens JL, van Baar AL, Verkerk G, van Son MM, de Vijlder JJ, et al. Low normal maternal free T4 concentrations during early pregnancy are associated with impaired psychomotor development in infancy. Clinical Endocrinology (Oxford) 1999; 50: 149-55.

96 Pop VJ, Brouwers EP, Vader HL, Vulsma T, van Baar AL, de Vijlder JJ. Maternal hypothyroxinaemia during early pregnancy and subsequent child development: a 3-year follow-up study. Clinical Endocrinology (Oxford) 2003; 59 : 282-8.

97 Delange F, de Benoist B, Pretell E, Dunn JT. Iodine deficiency in the world: where do we stand at the turn of the century? Thyroid 2001; 11: 437-47.

98 Fisher DA, Hobel CJ, Garza RBS, Pierce CA. Thyroid function in the preterm fetus. Pediatrics 1970; 46: 208-16.

99 Hume R, Simpson J, Delahunty C, van Toor H, Wu SY, Williams FL, et al. Human fetal and cord serum thyroid hormones: developmental trends and interrelationships. Journal of Clinical Endocrinology and Metabolism 2004; 89: 4097-103.

100 Persani L, Borgato S, Romoli R, Asteria C, Pizzocaro A, Beck-Peccoz P. Changes in the degree of sialylation of carbohydrate chains modify the biological properties of circulating thyrotropin isoforms in various physiological and pathological states. Journal of Clinical Endocrinology and Metabolism 1998; 83: 2486-92.

101 Morreale de Escobar G, Obregón MJ, Escobar del Rey F. Maternal thyroid hormones early in pregnancy and fetal brain development. Best Practice \& Research in Clinical Endocrinology and Metabolism 2004; 18: 225-48.

102 Heinrichs C, de Zegher F, Vansnick F, Vokaer A, Chistophe C, Frankenne F. Fetal hypopituitarism: perinatal endocrine and morphological studies in two cases. Acta Paediatrica 1994; 83: 448-51.

103 Perelman AH, Johnson RL, Clemons RD, Finberg HJ, Clewell WH, Trujillo L. Intrauterine diagnosis and treatment 
of fetal goitrous hypothyroidism. Journal of Clinical Endocrinology and Metabolism 1990; 71: 618-21.

104 Abuhamad AZ, Fisher DA, Worsof SL, Slomick RN, Pyle PG, Wu SY, et al. Antenatal diagnosis and treatment of fetal goitrous hypothyroidism: case report and review of the literature. Ultrasound in Obstetrics and Gynecology 1995; 6: $368-71$.

105 Chan LY, Leung TN, Lau TK. Influences of perinatal factors on cord blood thyroid-stimulating hormone level. Acta
Obstetricia et Gynecologica Scandinavica 2001; 80 1014-8.

106 Choudbury N, Gorman KS. Subclinical prenatal iodine deficiency negatively affects infant development in Northern China. Journal of Nutrition 2003; 133: 3162-5.

107 Nohr SB, Laurberg P. Opposite variations in maternal and neonatal thyroid function induced by iodine supplementation during pregnancy. Journal of Clinical Endocrinology and Metabolism 2000; 85: 623-7. 